\title{
Practical Theology as part of the landscape of Social Sciences and Humanities - A transversal perspective
}

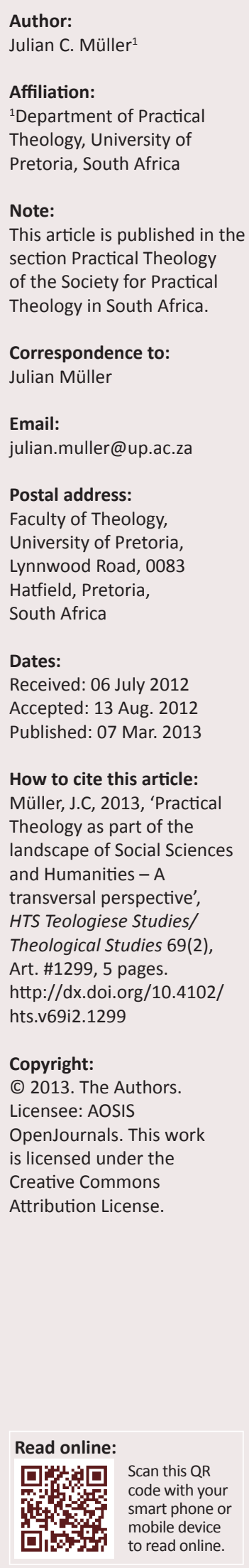

At the University of Pretoria the author, a practical theologian, experiences a fruitful soil for the development of an interdisciplinary process. He referred to concrete examples of cooperation, but used the article to reflect on best practices for the interdisciplinary dialogue. He came to the conclusion that it probably made more sense to talk of Practical-theological alternatives rather than to describe the subject in a single fixed manner of understanding and action. Our goal should rather be to open up the boundaries between Practical Theology, Human, Social and Natural Sciences.

\section{Introduction}

\section{Practical Theology: Moving between fields}

Practical theology is known for its fluidity and dynamics which enables it to move eloquently between various fields of study. Subsequently, this field tends to move on a continuum of polarities, where it can at one moment incline to the side of dogmatics, whereas at other times to the side of arts. Practical theologians as such, have the freedom to move to and fro between these two polarities. Take note that the force behind these movements comes from the specific and localised context, which creates both an imperative and directness of movement.

The localised context of this article is the University of Pretoria, where the author works as a practical theologian at the Faculty of Theology. Being a faculty of a university, the context provides for interdisciplinary contacts and interaction. This is one of the advantages of a university faculty of theology in contrast to an independent theological seminary. The challenges for interdisciplinary cooperation have not been explored to its full potential and the aim of this article will be to provide another stimulus towards the development for more cooperation at various levels. Through the years there have been several successful efforts of interdisciplinary engagement. For many years the first practical theologian of the Faculty of Theology, Prof. H.D.A. $\mathrm{du}$ Toit was responsible for teaching a module on 'Church Welfare' to the graduate students from the Department of Social Work. This arrangement was the result of an agreement where social workers from the Dutch Reformed Church received their training at the University of Pretoria. The interdisciplinary approach also becomes visible in various joint research projects, for instance on the theme of HIV and AIDS. The author of this article has led such a team-based research project on the 'Unheard stories of people infected and affected by HIV and AIDS, about care and the lack of care.' Scholars of various social sciences cooperated with this project.

The purpose of this article is not to give a report of the history of cooperation between theology and social sciences, but rather to provide further reflection on the epistemological basis for interdisciplinary work from the perspective of transversal rationality, including a specific and localised focus, based on a postfoundational approach, as it is emphasised by Van Huyssteen (2006b):

... in interdisciplinary dialogue the rather a-contextual terms 'theology and science' should be replaced by focussing our attention on specific theologians, engaging in specific kinds of theologies, who are attempting to enter the interdisciplinary dialogue with very specific scientists, working within specific sciences on clearly defined, shared problems. (p. 151)

Bochner and Ellis's (1996) statement regarding ethnography is also in accordance with this approach and can be seen as true for practical theology:

It's not the name of a discipline. Ethnography is what ethnographers do. It's activity. Ethnographers inscribe patterns of cultural experience; they give perspective on life. They interact, they take note, they photograph, moralise, and write. (p. 16)

Therefore the practical theologian transforms his or her form: sometimes he or she takes the shape of an exegete or a dogmatist; at other times, he or she is camouflaged as an artist and a poet.

Nonetheless, as scholars we still work in a structured and systemised environment, where practical theology as a discipline, finds itself amidst a series of theological and non-theological 
disciplines. It is also true that the traditional encyclopaedia of academic disciplines tend to divide the various spectrums of disciplines into watertight compartments, which is no longer sustainable. Too often these disciplines were sustained for the sake of the size of the university's budget or for the sake of building a career and identity for academic scholars. However, it remains a reality that scholars need to consider their relationship both with their own, other theological and non-theological disciplines. Practical theology has some advantages when compared with other theological disciplines. It is a relatively young discipline which has a history of reflection as well as a struggle with finding its own identity as a valid discipline. Concepts such as transversal reasoning and the degree of transversality can contribute to an even better understanding and placement of this discipline within the greater academic landscape.

\section{The unfolding of the landscape}

Traditionally human sciences focus mainly on the totality of a person's life, which includes concepts related to values and purpose (cf. Losch 2005:281). The agents of this focus include disciplines such as, classics, history, archaeology, languages, art, literature, philosophy and theology. At the end of the 19th century, the so-called 'gamma-sciences' came to the foreground with their attention focused on the study of human behaviour in relation to their social environment. Drenth (2008) describes the nature of this focus as follows:

The nature and development of human cognitive and emotional functions, the interactions of individuals with their social environment, the structure and dynamics of social systems with regard to cultural, constitutional, economic and socio/political aspects, all became the object of scientific analysis in various (main) disciplines: psychology, sociology, economics and political science. (p. 41)

Other sub-disciplines, which evolved from these disciplines, to mention a few are demography, criminology, cultural anthropology and education and management sciences. Therefore, the three primary categories are behavioural sciences, social sciences and economical sciences. Drenth (2008) states:

The study of human beings and human social structures does not only deal with Dawkins' 'living things' of biology as opposed to 'dead things' of physics, but with living things that have motives, intentions, norms and values, and whose social institutions have meanings, symbols, rules and rituals, all of which are not directly measurable, but have to be inferred from observables. (p. 41)

Social sciences, nonetheless developed strong empirical values and as such, phenomena that are not only observed and studied, but also measured with empirical methods.

\section{The positioning of practical theology}

Gräb (2005:181) comments on Friedrich Schleiermacher's discussion as a practical theologian, by stating that Schleiermacher's understanding of practical theology as an independent discipline overcomes the tendency of seeing practical theology as an applied science. Schleiermacher took this stand against his former contemporary, Gottlieb
Jakob Planck (1751-1833), who viewed practical theology as subordinate to other theological disciplines and described practical theology as an applied theology, theologia applicata (Gräb 2005:182).

The development of modern practical theology is mostly based on Schleiermacher's understanding of it as a science that studies Christian religion as it is found in the praxis of a person's life (Gräb 2005:182). As Gräb (2005) states:

Practical Theology needs to explore how the symbolic strength of Christianity for making sense of life and for successfully coping with life can take shape in the church under today's complex socio-cultural conditions. (p. 196)

If viewed in this way, it is clearly inevitable that practical theology will lean on the social sciences for its description and understanding of human behaviour within the context of religion. Therefore, practical theology as a modern academic science has developed strongly to the likeliness of social sciences (cf. Van der Ven 1990; Heitink 1993; Browning 1991; Pieterse 1993). It went through a phase of adopting and depending upon the methods of social sciences. Johannes van der Ven (according to Cartledge 1999:98) was innovative in introducing the intra-disciplinary method, with which he integrates social-scientific methods within a theological frame of reference. The concept 'intra-disciplinary' refers to the idea of borrowing concepts, methods and techniques from other disciplines that are then integrated within the study of another science. With reference to this, Cartledge (1999:103) states: '... empirical methodology enables practical theology to study religious convictions, beliefs, images and feelings of people. It has both descriptive and explanatory value.'

In his article, De Villiers (2004:103) investigates the impact of social development on various religions and the disciplines that study these religions as a result of a new political environment. He postulates thus, that in a new South Africa, religion and academic disciplines that are dedicated to the exclusive study of religion, need the input of social sciences especially with reference to insights regarding the processes of modernism, secularisation, individualism and globalisation (De Villiers 2004:117). Therefore, it is also necessary for theology to estimate the degree to which the situation in South Africa allows for organised religions and theology to have an influence on the public sphere. According to De Villiers (2004:120), theology needs to be challenged by the social sciences whenever the various cultivated views of religion have a negative influence on society.

Consequently, the complex nature of religious experiences forces us continuously in the direction of social sciences and arts. Germond (2001:30-31) states that development is as much about people and their experiential world as it is about physical and social development. He (Germond 2001) quotes Foucault, who said:

What strikes me is the fact that, in our society, art is now only linked to objects rather than to individuals or to life itself. This kind of art is specialised, or produced by experts who are artists. But couldn't we ourselves, each one of us, make our life a work of art? Why should a lamp or a house become the object of artand not our own lives? (pp. 30-31) 
In line with this thinking, we can perhaps propose and promote a practical theology where the lives of all people, especially the disadvantaged and the marginalised, are seen as 'a work of art.' Hence, we have an approach that rests on empirical data, whilst at the same time moving beyond the boundaries of social sciences.

\section{Degrees of transversality between theology, social sciences and human sciences}

Transversality is the language used within the postfoundational thought that enables meaningful communication between the diverse disciplines (cf. Müller 2009). Additionally transversal rationality opposes the language of universality on the one hand and diverse rationality on the other.

Universal rationality developed from a fundamental understanding of reality, which takes the position that a 'God's eye view' is available and that only one theoretical truth can exist. If working from this position, an interdisciplinary conversation becomes very difficult and even impossible, because one's own discipline is taken for granted and regarded as the truth. The acceptance of this 'truth' becomes the basis on which other disciplines enter the conversation, if they are prepared to accept this postulation as 'truth'. With the acceptance of such rationality the only options available are the assimilation and accommodation of other insights. A conversation on equal grounds is impossible. The so-called 'intra-disciplinary' approach in which the methods and techniques of other disciplines are learned and applied (Van der Ven 1993) runs the same danger.

Diverse rationality on the other hand is part of a nonfundamental approach. Whereas the previous approach works from a universal truth that is accessible, this one tends to be the opposite rational. A fundamental truth does not exist and we only have a diversity of perspectives:

In our times the concept of a universal truth is no longer accepted. The challenge raised by postmodern theories, such as Foucault's understanding of knowledge/power, cuts at the foundationalist assumption of the 'university.' Perhaps a so-called 'multiversity' takes no assumption for granted and is continually critical even of itself in a scheme of multiple rationalities and democratic organisation, devoted to reducing the force of the power/ knowledge matrix. (Tatusko 2005:114)

Interdisciplinary conversation is according to this approach, interesting but in essence meaningless, as with a diversity of meanings progress cannot be made towards any new understanding. Tolerance of each other's positions is the most that can be expected.

From the perspective of transversal rationality both the above mentioned positions are viewed with suspicion, because there is a realisation of both the danger of relativity (diverse rationality) and subjectivity (universal rationality). This approach therefore distances itself from both the fundamental and non-fundamental claims:
From radical hermeneutics we learn that [for humans] there is no truth at the bottom of being, no final, bedrock, correct interpretation [because of the limits of understanding and of expression] that supplies the Letztebegründung. The search for such is misguided ... On the other hand, the hurried and facile claim of relativism that every interpretation is as good as every other, is equally misguided. As no finite mind is privy to an absolute, strictly univocal, and timeless interpretive truth, so no finite mind can achieve a vision of all interpretations, which is required for the judgment that all interpretive claims are relative (Schrag 1992:75).

Transversal rationality is a concept that was formulated by scholars such as Schrag and Van Huyssteen. It is an attempt to envision a responsible and workable, tangent point between disciplines. In the words of Van Huyssteen (2006a):

In this multidisciplinary use of the concept of transversality there emerge distinct characteristics or features: the dynamics of consciousness, the interweaving of many voices, the interplay of social practices are all expressed in a metaphor that points to a sense of transition, lying across, extending over, intersecting, meeting, and conveying without becoming identical. (p. 19)

Van Huyssteen (2007:421) states that 'transversal reasoning' isn't about arbitrarily opening or closing yourself up to other viewpoints, but rather to discover an epistemic space where all kinds of interdisciplinary critical evaluation is possible, which includes critical self-evaluation and 'optimal understanding.' However, he is of the opinion that the interdisciplinary conversation has natural limitations: 'In the transversal, interdisciplinary moment rich resources could be shared, but after this moment, a post-foundational approach points back to the contextual, natural, intra-disciplinary boundaries of our own disciplines' (Van Huyssteen 2007:421). Van Huyssteen (2007:422) is of the opinion that 'transversal reasoning' should be aware of the 'degrees of transversality' and that different theological approaches will have different degrees of success in interdisciplinary conversation: 'It is however most important, that theology and the sciences share concerns and can converge in their methodological approaches on specifically identified problems.'

Losch (2005:280) refers to Barbour who wrote that the contrast between religion and science should always be kept in mind but that 'the contrasts are not as absolute as most recent theologians and philosophers have maintained.' He refers to both Barbour and Polkinghorne who acknowledge '... only a difference in degree between the divergent disciplines':

When our rational inquiry moves us from physical to personal science, according to Polkinghorne, the deeper our encounter with reality becomes; likewise, the more cultural factors play a part because the dependence on tacit skills of judgment increases. (Losch 2005:280)

A new approach to ethnography shines light on the new approach to practical theology that comes to the fore in especially the narrative and postfoundational approach to practical theology. This 'new ethnography' moves closer to the social sciences. It works qualitatively and with the perspective that people's lives are 'works of art'. As such it is interested in concrete persons - people with smell, 
taste, desire and thoughts and at the same time with the practical theologian's own world of experience. To practice practical theology within this framework of thought requires intellectual and emotional adaptability, which is easier within a postmodern and postfoundational practical theology. It then makes conversation with natural and other sciences possible without creating anxiety.

Ellis and Bochner (1996:18) state: 'The walls between social sciences and humanities have crumbled.' This is of the utmost importance for the understanding and positioning of practical theology. During the last three decades schools of thought within the world of practical theology have developed that were aimed at the linking of the discipline to social sciences. Consequently, a strong focus on empirical methodology within the discipline of practical theology developed. Practical theologians became specialists in the methods (quantitative and qualitative) of social sciences. This was beneficial to the discipline in many ways and made it possible for practical theologians to stand their ground in the interdisciplinary circle of academics.

Recently postfoundational ideas were employed to develop a new understanding of practical theology (cf. the works of Müller 2003, 2009; Osmer 2006; Newlands 2006).

According to this understanding of Practical Theology (cf. Müller 2011:3 of 5) stories of people in real life situations have priority. The aim is not the description of a general context, but to confront us with a specific and concrete situation. According to Van Huyssteen (2006a:10) '... embodied persons, and not abstract beliefs, should be seen as the locus of rationality. We as rational agents are thus always socially and contextually embedded.'

This way of thinking is always concrete, local, and contextual, but at the same time it reaches beyond local contexts to transdisciplinary concerns. It is contextual, but at the same time in acknowledgement of the way in which our epistemologies are shaped by tradition. Van Huyssteen (2006a:22) refers to the postfoundationalist notion as 'a form of compelling knowledge', which is a way of seeking a balance between 'the way our beliefs are anchored in interpreted experience, and the broader networks of beliefs in which our rationally compelling experiences are already embedded' (see Müller 2011:3 of 5).

The postfoundational understanding consists of a shift of emphasis from individual to social, from subjective towards discourse (cf. Müller 2011:3 of 5). As Van Huyssteen (2006a) argues:

Because of our irrevocable contextuality and the embeddedness of all belief and action in networks of social and cultural traditions, beliefs, meaning, and action arise out of our embedded life worlds. (p. 24)

According to Van Huyssteen (1997) a postfoundationalist notion of rationality should open our eyes to an epistemic obligation that points beyond the boundaries of our own discipline, our local communities, groups or cultures, toward plausible forms of interdisciplinary dialogue. In his Gifford Lectures, Alone in the World? (2006a) he says:

A postfoundationalist approach helps us realise ... that we are not the intellectual prisoners of our contexts or traditions, but that we are epistemically empowered to cross contextual, cultural, and disciplinary borders to explore critically the theories, meanings, and beliefs through which we and others construct our worlds. (p. 25; see Müller 2011:3 of 5)

Van Huyssteen (2006b:147) repeats the very important notion of a 'democratic presence' for Christian theology in an open, postfoundationalist conversation. Theology shares the interdisciplinary standards of rationality, which will not be hopelessly culture and context bound, but will always be contextually and socially shaped. In this interdisciplinary conversation with other sciences, theology will act as an equal partner with an authentic voice in a postmodern situation (see Müller 2011:3 of 5).

\section{Conclusion}

Different contexts and fields of research ask for different approaches. The result is a practical theological approach that does not look the same everywhere. Sometimes it is similar in nature and methodology to the quantitative and qualitative methodology of the social sciences. At other times, it is narrative in nature and more oriented towards the arts. In my own approach to the discipline, I make the distinction between the narrative metaphor according to which I practice practical theology and narratology. The latter is based on the knowledge of narratives as a phenomenon and the ability to analyse and interpret the narratives. It therefore also works with stories, but is structuralistic and analytical in the analysis thereof.

In line with the idea of levels of transversality, it probably makes more sense to talk of practical-theological alternatives ${ }^{1}$ rather than to describe the subject in a single fixed manner of understanding and action. Our goal should rather be to open up the boundaries between practical theology, human, social and even natural sciences. In doing so, we can enrich and broaden our sensitivity towards the human condition and human society as well as the religious community. It will hopefully, also bring us to develop a greater sensitivity for the marginalised in society. In fact, it is precisely there where specific needs are seen, described and investigated from different perspectives, that practical theology can make a unique contribution.

\section{Acknowledgements Competing interests}

The author declares that he has no financial or personal relationship(s) which may have inappropriately influenced him in writing this article.

1.According to 'ethnographic alternatives' by Ellis and Bochner (1996:19). 


\section{References}

Bochner, A.P. \& Ellis, C., 1996, 'Talking over ethnography', in C. Ellis \& A.P. Bochner (eds.), Composing Ethnography: Alternative forms of qualitative writing, pp. 13-45, Sage Publications, Walnut Creek, London/New Delhi.

Browning, D., 1991, A fundamental Practical Theology, Fortress Press, Minneapolis, MN.

Cartledge, M.J., 1999, 'Empirical theology: Inter- or intra-disciplinary?', Journal of Beliefs \& Values 20(1), 98-104. http://dx.doi.org/10.1080/1361767990200109

De Villiers, E., 2004, 'Religion, theology and the social science in a society in transition', HTS Teologiese Studies/Theological Studies 60(1/2), 103-124. http://dx.doi.org/ 10.4102/hts.v60i1/2.522

Drenth, P.J.D, 2008, 'Social sciences: Truthful or useful?', European Review 16(1), 39-53. http://dx.doi.org/10.1017/S1062798708000057

Ellis, C. \& A.P. Bochner (eds.), 1996, Composing ethnography: Alternative forms of qualitative writing, Sage Publications/Walnut Creek, London/New Delhi.

Germond, P., 2001, 'Theology, development and power: Religious power and development practice', Journal of Theology for Southern Africa 110(July), 21-31.

Gräb, W., 2005, 'Practical Theology as theology of religion: Schleiermacher's understanding of practical theology as a discipline', International Journal of Practical Theology 9, 181-196. http://dx.doi.org/10.1515/ijpt.2005.9.2.181

Heitink, G., 1993, Practical Theology, William B. Eerdmans, Grand Rapids, MI. PMid:8333911

Losch, A., 2005, 'Our world is more than physics: A constructive-critical comment on the current science and theology debate', Theology and Science 3(3), 275-290. http://dx.doi.org/10.1080/14746700500317271

Müller, J.C., 2003, 'HIV/AIDS, narrative practical theology, and postfoundationalism: The emergence of a new story', HTS Teologiese Studies/Theological Studies $60(1 / 2)$ 293-306. http://dx.doi.org/10.4102/hts.v60i1/2.516
Müller, J.C., 2009, Postfoundationalism as a Practical Way of Interdisciplinary Dialogue: Narrative Research on HIV and Aids, CG Publishers, n.p.

Müller, J.C., 2011, 'Postfoundational Practical Theology for a time of transition', HTS Teologiese Studies /Theological Studies 67(1), 5 pages. http://dx.doi.org/10.4102/ hts.v67i1.837

Newlands, G., 2006, 'Public Theology in postfoundational tradition', in F.L. Shults (ed.), The Evolution of Rationality: Interdisciplinary essays in honor of J. Wentzel van Huyssteen, pp. 394-417, William B. Eerdmans, Grand Rapids, MI.

Osmer, R.R., 2006, 'Toward a transversal model of interdisciplinary thinking in Practical Theology', in F.L. Shults (ed.), The Evolution of Rationality: Interdisciplinary essays in honor of J. Wentzel van Huyssteen, pp. 327-345, William B. Eerdmans, Grand Rapids, MI.

Pieterse, H.J.C., 1993, Praktiese Teologie as kommunikatiewe handelingsteorie, RGNUitgewers, Pretoria. (RGN-studies in Praktiese Teologie).

Schrag, C.O., 1992, The resources of rationality: A response to the postmodern challenge, Indiana University Press, Bloomington, IN.

Tatusko, A.M., 2005, 'The tacit media pedagogy as praxial critique: A critique of postmodern theory for Higher Education Curriculum', Teachers College Record postmodern theory for Higher Education Curriculum', Teachers College
$107(1), 114-136$. http://dx.doi.org/10.1111/j.1467-9620.2005.00459.x

Van der Ven, J.A., 1993, Entwurf einer empirische Theologie, J.H. Kok, Kampen.

Van Huyssteen, J.W., 1997, Essays in postfoundationalist theology, William B. Eerdmans, Grand Rapids, MI. PMid:16645122

Van Huyssteen, J.W., 2006a, Alone in the world? Human uniqueness in science and theology: The Gifford lectures, William B. Eerdmans, Grand Rapids, MI.

Van Huyssteen, J.W., 2006b, 'When our bodies do the thinking: Theology and science converge', American Journal of Theology \& Philosophy 27(2), 127-153.

Van Huyssteen, J.W., 2007, 'Response to critics', American Journal of Theology \& Philosophy 28(3), 409-432. 